\title{
Determination of Upper and Lower Limits of Concession Period for PPP Projects Using Probabilistic NPV
}

\author{
Mohamed M. Elbaz ${ }^{1}$, and Adel I. Eldosouky ${ }^{2}$ \\ ${ }^{1}$ Structural Engineering Department, Mansoura Higher Institute for engineering and Technology, Egypt \\ ${ }^{2}$ Structural Engineering Department, Faculty of Engineering, Tanta University, Egypt
}

\begin{abstract}
This paper provides a methodology to determine the upper and lower limits of concession period of public private partnerships that would be useful both to the public and the private sector with the impact of risks and uncertainties taken into consideration. The model uses Monte Carlo simulation to evaluate the effect of risks and uncertainties on the concession period. Net present value (NPV) analysis is used for financial evaluation. To demonstrate the applicability of the proposed model, hypothetical public private partnership (PPP) rail way project in Egypt was used a case study. After applying the model accurate results are obtained. However, using this model gives the practitioners a clearly vision about the value of concession period insuring that the private sector doesn't lose his investment and the government can benefit from the project before end of its service life.
\end{abstract}

Keywords: Risk, (PPP), (NPV), Uncertainty, Payback period, (NAV), (IRR).

\section{INTRODUCTION}

The challenges of meeting the huge infrastructure needs of most developing countries caused by increased population and budget constraints have influenced most government agencies to shift from the conventional procurement systems to more innovative types of procurement.

One popular option for meeting these demands for infrastructure projects and improvement in service level has been private investment through concession agreements such as the Build Operate and Transfer (BOT). The use of public private partnership (PPP) types of contract for the development of infrastructure projects has gained considerable acceptance and is becoming popular in many countries around the world. The PPP arrangement enables clients to have access to funds for the delivery of capital projects through financing partnership between a private and public agency with the parties receiving concessions on design, planning, financing, execution and management of projects [1].

This paper discussed the model used for determination of upper and lower limits of concession period of PPP projects. An accurate explanation of model inputs, outputs and methodology of work presented. Then the model is applied on a case of high-speed rail PPP project and accurate results were obtained.

\section{LITERATURE REVIEW}

A. $P P P$

PPP are contractual agreements between public agencies and private companies. Under such an agreement a private company or a consortium of several companies is granted a concession to finance, build, and operate a public project and to provide the corresponding product or service and collect ensuing revenues. Project revenues can be used to repay the debt, recoup equity investment, and achieve a reasonable level of profit [2].

\section{B. Concession period}

The most popular PPP option is the concession-based type such as build-own-operate-transfer in which the private partner (concessionaire) undertakes to finance, design, construct, operate and maintain the facility during a concession period that is usually determine by their public counterpart at the outset. In return, the concessionaire well recovers their capital investment through the operation revenue over the concession period [3].

The determination of the concession period is of great importance to the success of a PPP contract. Generally, a longer concession period is preferred by private investors but may bring loss to the government. However, if the concession period is too short, the private investor may reject the contract or have to increase the service fee so as to recoup the investment costs and make a profit, which consequently transfers the risk burden to public users [4]. Junna et al. (2014) used real options theory to identify an effective interval of concession period for a PPP transportation project and Nash negotiation theory is applied to find the optimal value of the concession period [5].

Sharma and Cui (2012) used a hybrid model that allows the public sector to determine the upper limit of availability payments and concession duration. The hybrid model has been developed by combining stochastic dynamic programming with multi-objective optimization principles. The model allows using private sector's financial condition, uncertainty of private sector's performance and the remaining life cycle costs of the asset. The use of this model ensures cost savings for the public sector and financial stability for the private sector simultaneously [6].

Bagui and Ghosh (2013) evaluated the mean net present value (NPV), variance and NPV-at-risk of different concession period structures, so that both the government and the concessionaires can understand their risk exposure and rewards. The paper then analyzed the influence of project characteristics on concession period design to evaluate the feasibility of the design. Expected concession period has been calculated using Monte Carlo simulation 
method [7].

Nasirzadeh et al. (2014) determined the concession period using a fuzzy logic-based methodology. The proposed approach accounts for the existing risks and uncertainties. In the proposed methodology, the interests of both parties would be ensured, and a win-win solution would be achieved [8].

Zhang and Abourizk (2006) proposed a methodology for the determination of an appropriate length of the concession based on a win-win principle for parties involved and exercises simulation techniques in measuring and evaluating construction and economic uncertainties and risks [9].

$\mathrm{Hu}$ and Zhu (2014) proposed an improved model based on a traditional concession model by taking into account the case that the government might lower the service price in the post transfer period to increase social welfare. This paper also introduced the optimal pricing methods for both concession and post transfer period. The proposed methodology suggested a narrower concession interval, which helps improve the negotiation efficiency between the government and the private investor to a certain extent [4].

Hanaoka and Palapus (2012) provided a methodology to determine the reasonable concession period that would be advantageous both to the government and the private sector with the impact of risks taken into consideration in the financial evaluation using Monte Carlo simulation and bargaining game theory. The simulation produced a range of concession period for the private sector and government to negotiate. Bargaining game theory was employed in an attempt to find a specific concession period [10].

Carbonara et al. (2014) provided a methodology to calculate the concession period as the best instant of time that creates a 'win-win' solution for both the concessionaire and the government and allows for a fair risk sharing between the two parties. In other words, the concession period is able to satisfy the private and the government by guaranteeing for both parties a minimum profit, and, at the same time, to fairly allocate risks between parties. In order to take into account, the uncertainty that affects the PPP projects, the Monte Carlo simulation was used [11].

Zhang (2009) has proposed a win-win concession period determination methodology, in which PPPs are addressed as a principal-agent maximization problem. Both deterministic and simulation-based methods are provided to determine the concession period, with detailed step-by-step procedures. These methods take into consideration the financial characteristics of PPPs and the construction and operation requirements [12].

Feng et al. (2018) firstly identified several key concessionary items, including concession period, concession price, capital structure and government subsidy. Then, a multi-objective optimization model is presented using discounted cash flow method, in which key concessionary items act as decision variables and public and private interests are represented by two sub-objectives. Subsequently, the model is solved using non-dominated sorting genetic algorithm [13].

Thomas et al. (2007) proposed a simulation model to assist public partners to identify the concession period based on the expected investment and tariff regime. The needs for establishing different scenarios to represent the risks and uncertainties involved are presented, and a fuzzy multiobjective decision model is introduced to trade-off the associated three concession items. The combined features of the simulation and fuzzy multi-objective decision models enable the scenario most likely to result in a "win-win-win" concession scheme to be identified [14].

Mostafa et al. (2015) implemented a Fuzzy-Delphi technique to determine the length of concession period considering uncertainties. Using the proposed Fuzzy-Delphi technique, the values of different uncertain factors affecting a PPP project is determined considering opinions of a group of experts. The NPV value is calculated considering the resulted aggregated values of uncertain input parameters. Finally, the concession period is determined using fuzzy approach [15].

Zhang et al. (2016) determined the optimal concession period life span by maximizing the combined benefits of stakeholders. Based on the estimation of the economic and social development involved, a negotiation space of the concession period interval is obtained, with its lower boundary creating the desired financial return for the private investors and its upper boundary ensuring the economic feasibility of the host government as well as the maximized welfare within the project life. The outcome of the new quantitative model is considered as a suitable basis for future field trials prior to implementation [16].

The aim of the present work is to construct a model to determine the upper and lower limit of concession period with effect of risks and uncertainties taken into consideration. However, little research to date has focused on this aspect.

\section{MODEL}

\section{A. Model Description}

The model is described for determining the payback period, Lower limit and Upper limit of concession period based on net present value (NPV) analysis with the effect of risks and uncertainties taken into consideration.

\section{B. Model Inputs}

The model inputs contain first construction cost, construction activities, toll rate, yearly operation and maintenance cost which assumed to be constant all over the operation period, operation revenue expected for every year of operation, internal rate of return expected from the private part from the project, number of passengers at first operation year and annual growth rate of passengers.

\section{Methodology}

A. Methodology for determination of payback period

1- Prepare required input data including interest rate given by the bank $(\mathrm{r})$, toll rate $\left(\mathrm{P}^{\circ}\right)$, yearly operation and maintenance cost $(\mathrm{Mc})$, number of passengers at first operation year $(\mathrm{Q} 1)$ and annual growth rate of passengers (a). 
2- Enter to the model the construction activities and activities durations.

3- Create a scheduling to construction activities to get construction period.

4- Enter the activities cost noting that all costs in the construction period is cash out and entered to the model with a negative sign.

5- Enter the operation period as an activity to the model with duration of one year (following construction activities with finish to start relationship).

6- For operation activity insert operation and maintenance cost (Mc) with negative sign and operation revenue $\left(\mathrm{Q}{ }^{*} \mathrm{P}^{\circ}\right)$ with positive sign. While $\mathrm{Qy}$ is number of passengers at operation year $\mathrm{Y}$. Noting that at first operation year Qy = Q1.

7- Define risks affecting construction and operation period and for each risk define probability and impact.

8- Run Monte Carlo simulation to get cumulative probability distribution of NPV.

9- Determine NPV according to Eq (1)



where:

$\mathrm{Ct}$ : construction cost at year $\mathrm{t}$

$\mathrm{t}_{0}$ : construction period

r: interest rate

Qy: number of users at year y

$\mathrm{P}_{0}$ :toll rate

Mc: yearly operation and maintenance cost

10- If NPV $=0$ the payback = construction period + one-year operation, else assume operation period $=$ two years and acquire anew project schedule.

11- determine number of passengers of the new operation year Qy = a (Y-1) + Q1 then go step 6. 12-) Continuo increase operation period by one year until get NPV $=0$ to get the payback period.

\section{B. Methodology for determination of Lower limit of Concession Period}

1-) Prepare required input data including IRR expected from the investor and payback period.

2-) After determining the payback period $(\mathrm{P})$ define a start milestone activity (Ic*R). The cost assigned to that activity equal ( $\mathrm{Ic} * \mathrm{R})$ while $\mathrm{Ic}$ is the investment cost and $\mathrm{R}$ is the expected IRR for investor. Noting that the value of Ic is changing with change of operation period.

3-) To calculate the lower limit of concession period an iterative process is used. The process starts by assuming the operation period (Y) equal the Payback period (determined before) Plus one year. Noting that operation period is contains activities with one-year duration for each activity.

4-) For each operation activity insert operation and maintenance cost $(\mathrm{Mc})$ with negative sign and operation revenue $\left(\mathrm{Qy}^{*} \mathrm{P}^{\circ}\right)$ with positive sign. While $\mathrm{Qy}=\mathrm{a}(\mathrm{Y}-1)$ + Q1.

5-) Insert the negative cost of the milestone activity (Ic*R). noting that $\mathrm{Ic}=\mathrm{Ct}+\mathrm{Mc}^{*} \mathrm{Y}$.

6-) Run Monte Carlo simulation to get cumulative probability distribution of NPV.
7-) Determine NPV according to Eq (2)

$$
\mathrm{NPV}=-\sum_{t=1}^{\mathbb{t}^{\mathrm{a}}}\left(\frac{c t}{(1+r)^{\mathrm{x}}}\right)+\sum_{t=t^{a}+1}^{T_{\varepsilon}}\left(\frac{Q y * P^{0}-M c}{(1+r)^{*}}\right)-I c * R
$$

where;

Ic: investment cost

$\mathrm{R}$ : expected IRR for investor

8-) If NPV $=0$ the concession period lower limit $=$ construction period + operation period else increase operation period by one year and acquire anew project schedule, then go to step 4.

9-) Continuo increase operation period by one year until get $\mathrm{NPV}=0$ to get concession period lower limit.

\section{Methodology for determination of Upper limit of Concession Period.}

1-) Prepare required input data including expected service life period for the project $(\mathrm{F})$, expected residual value of the project after the end of service life (RV) and concession period lower limit (L).

2-) After determining the lower limit of concession period define a start milestone activity (NAV). The cost assigned to that activity equals Net Asset Value (NAV). Noting that the value of NAV is changing with change of Y.

3-) Enter the cost of construction activities, start milestone activity $(\mathrm{Ic} * \mathrm{R})$ and operation activities before the lower limit equal zero.

4-) To calculate the upper limit of concession period an iterative process is used. The process starts by assuming the operation period (Y) equal the lower limit (determined before) Plus one year.

5-) For each operation activity from $Y$ to the end of service life period insert operation and maintenance cost (Mc) with negative sign and operation revenue $\left(\mathrm{Qy}^{*} \mathrm{P}^{\circ}\right)$ with positive sign. While Qy = a (Y-1) + Q1.

6-) Insert the negative cost of the milestone activity (NAV).

$$
\text { Noting that } N A V=C-\left(\frac{C-R v}{F} * y\right)(3) \text {. }
$$

7-) Run Monte Carlo simulation to get cumulative probability distribution of NPV.

8-) Determine NPV according to Eq (4)

$$
\mathrm{NPV}=\sum_{t=T C+1}^{T_{\mathrm{a}}+F}\left(\frac{Q y * P_{0}-M c}{(1+r)^{t}}\right)-(N A V)
$$

where:

F: service life of the project

NAV: net asset value at transfer time

9-) If NPV $=0$ the concession period upper limit = construction period + operation period else increase operation period by one year and acquire new project schedule, then go step 5 again.

10) Continuo increase operation period by one year until get $\mathrm{NPV}=0$ to get concession period upper limit.

\section{CASE Study}

\section{A. Case Study Project description}

A hypothetical case study of $220 \mathrm{~km}$ double-track high speed railway project is presented in this study. The project 
is assumed to run between Cairo and Alexandria parallel to Cairo Alex Desert highway.

\section{B. Construction Duration and Cost}

The cost for line and trains is estimated as presented in Table (1) based on costs obtained from the International union of railways. The construction period consists of four activities with finish to start relationship as given in Table (2). Table (3) shows the cost of each activity. currency used for all costs and revenues is euro because the reference of all costs is International union of railways which have euro $(€)$ is the basic unit ( $€=$ LE19.48) [17].

\section{Maintenance Cost for Line and Trains}

The yearly maintenance cost for line and trains is given in table (4) based on costs obtained from International union of railways.

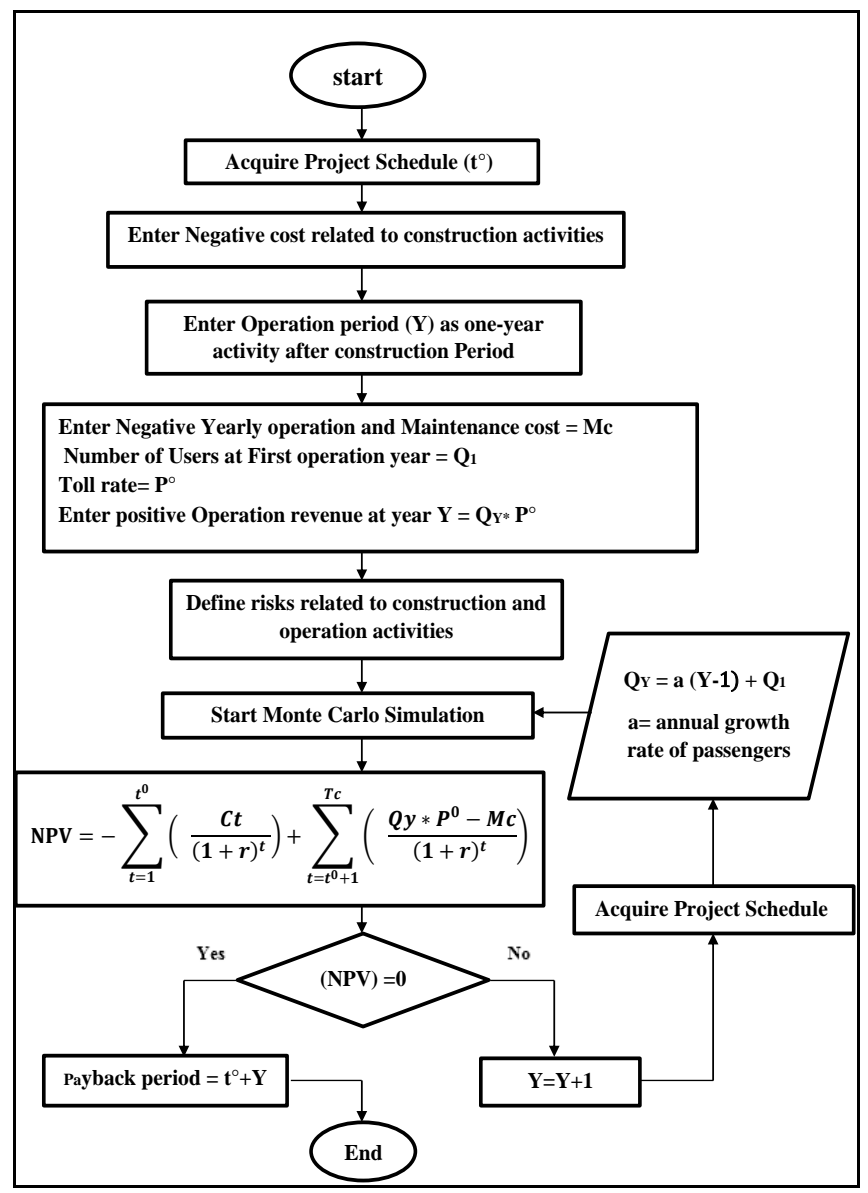

Figure 1. Flowchart for Determination of Project Payback Period

TABLE (1)

PROJECT ESTIMATED CONSTRUCTION COSTS

\begin{tabular}{|c|c|c|}
\hline \multicolumn{3}{|c|}{ Construction cost for HSL } \\
\hline $\begin{array}{c}\text { Number of } \\
\text { kilos }\end{array}$ & $\begin{array}{c}\text { Construction cost for } \\
\text { one kilo }\end{array}$ & Total Construction cost \\
\hline 220 & $€ 15,000,000$ & $€ 3,300,000,000$ \\
\hline \multicolumn{3}{|c|}{ Cost of a high-speed train (350 places) } \\
\hline $\begin{array}{c}\text { Number of } \\
\text { Trains }\end{array}$ & Cost of One Train & Total Trains Cost \\
\hline 4 & $€ 30,000,000$ & $€ 120,000,000$ \\
\hline
\end{tabular}

\section{Other financial data related to the project}

Interest rate given by the bank equal $9 \%$. No loans or insurance during construction or operation period.

\section{E. Operation Revenue}

The operation period is assumed to start on $2 / 1 / 2025$. The operation revenue of this project is ticket prices collected from passengers. To calculate the revenue, it is necessary to determine the ticket prices and predict the number of passengers in each year during the operation period. For ticket price It is assumed that all costs are constant along operation period including maintenance cost and also ticket price. Ticket price in this project is assumed $€ 15$. This price was assumed based on the literature. The number of passengers predicted in each year is determined in Table (5). A $\pm 30 \%$ uncertainty in number of passengers is taken into consideration when determining the revenue [18].

\section{F. Risk Identification}

Management of risks in a project requires identifying each risk as a first step in risk analysis. Risk identification is considered a very important stage, because all other steps and actions are dependent on the identified potential risks as presented in Table (6). This was done primarily through several studies [19 - 27].

To determine the probability and impact of each risk, interviews were conducted with eleven stakeholders in railway projects in Egypt. It contained questions that help to achieve the objective of the study such as risks probability and impact and the activities affected by these risks. Then create a list of these information which called Risk Register.

\section{G. Data required}

- Interest rate $(r)=9 \%$

- internal rate of return expected from the private part $(\mathrm{IRR})=14 \%$

- annual growth rate of passengers $(\mathrm{a})=826,333$ passenger.

- Toll rate (Ticket price) $\left(\mathrm{P}^{\circ}\right)=15$ euro

- yearly operation and maintenance cost $(\mathrm{Mc})=$ 23,800,000 Euro

- Uncertainty used of all duration and cost values is positive or negative $30 \%$

- number of passengers at first operation year (2025) $(\mathrm{Q} 1)=26,094,995$ passenger

\section{H. Payback period}

1- Identify the construction activities and their durations.

2- Develop a schedule to get the construction period. In this project construction period equal 5 years begin $1 / 1 / 2020$ and finish 31/12/2024.

3- Enter the activities cost noting that all costs in the construction period is cash out and entered to the model with a negative sign.

4- define a start milestone activity (Trains). The cost assigned to that activity equals Total trains cost.

5- Enter the operation period as an activity to the model with duration of one year.

6- Enter the cost of the operation activity. The cost consists 
of two parts. Part one is operation and maintenance cost which entered to the model with a negative sign and part two is cash in from passengers which entered to the model with a positive sign. Noting that cash in from passengers in one year $=$ toll rate $*$ number of passengers in that year.

7- The project now consists of 5 normal activities each activity has duration and cost. The total duration is 6 years, Fig (4).

8- Enter the bank interest rate equal $9 \%$.

9- Enter the uncertainty of costs and durations the uncertainty used in this case study is $\pm 30 \%$.

10- Enter the probability and impact of each identified risk, triangle distribution is used to represent the impact of risks.

11- Run Monte Carlo simulation to get the cumulative probability distribution of the NPV.

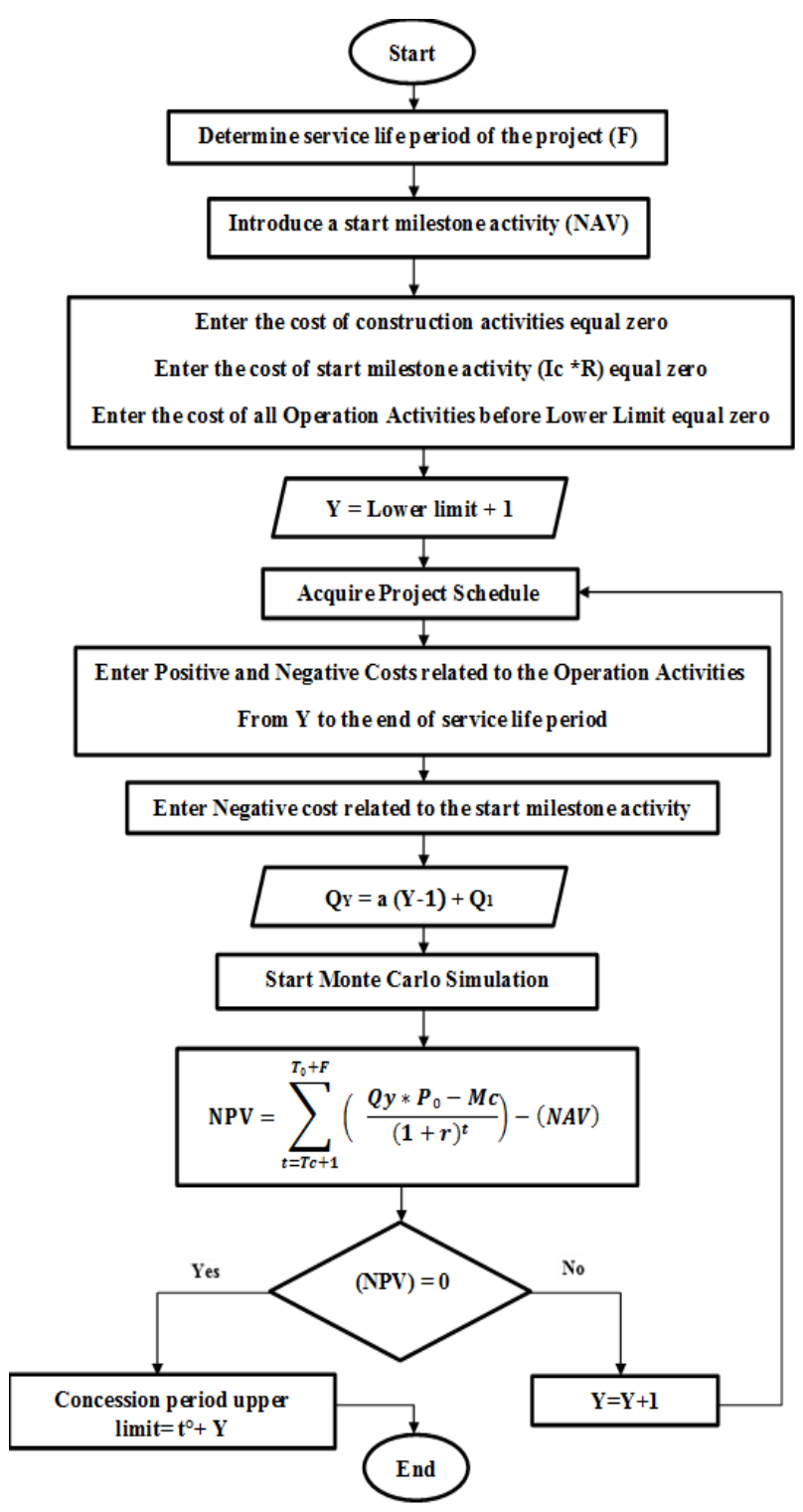

Figure 2. Flowchart for Determination of Lower Concession Period
12- If the NPV $=0$ then the payback period equal 6 years else assume the operation period two activities every activity has duration of one year and acquire anew project schedule, then return to step 6 .

13- Continuo increasing the operation period by one year until the NPV $=0$ to get the payback period.

14- In this case study, the NPV $=0$ will be found after 13 years' operation which mean the payback period equals 18 years. ( 5 construction years +13 operation years).

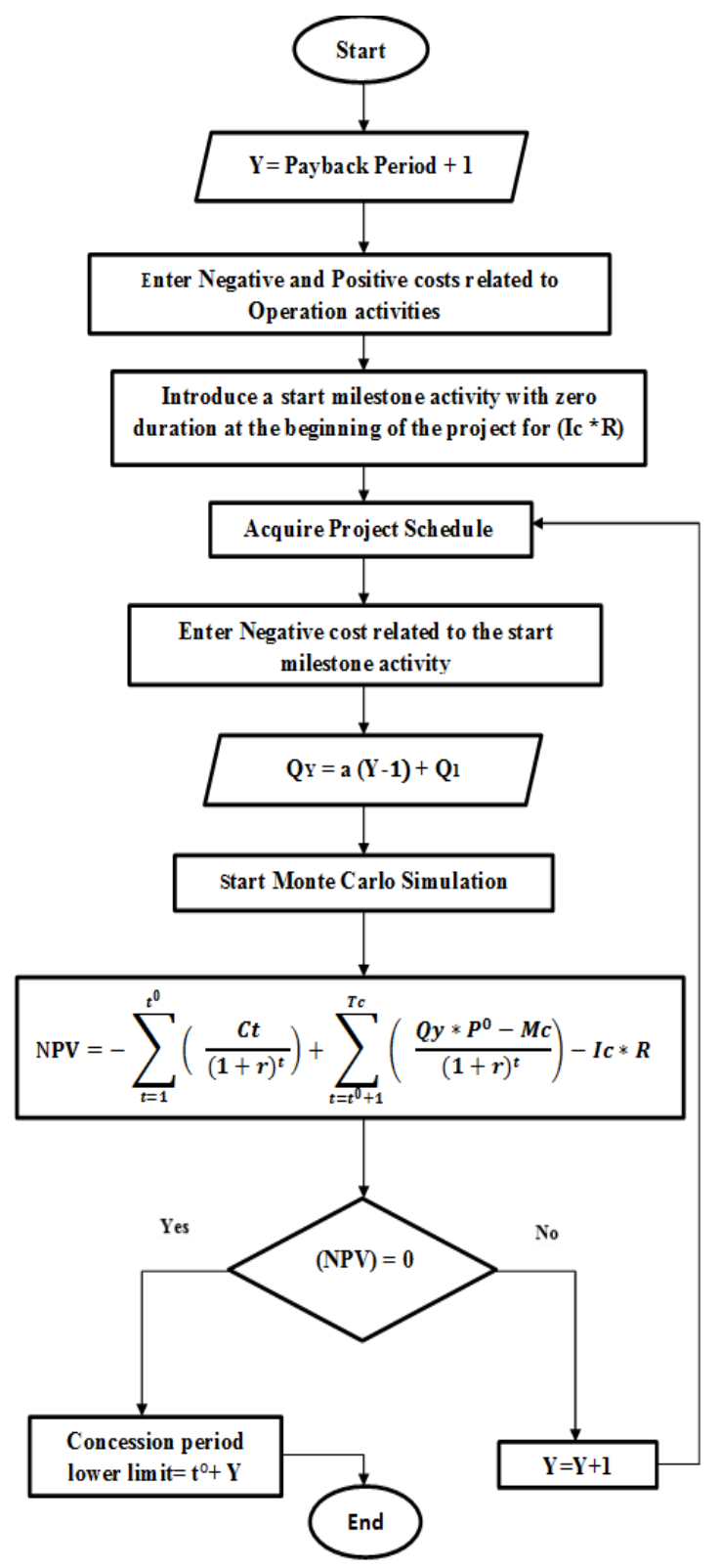

Figure 3. Flowchart for Determination of Upper Concession Period

\section{Lower Limit Concession period}

1- After determining the payback period $(\mathrm{P})$, define a start milestone activity (Ic*R). The cost assigned to that activity equals (Ic*R) while Ic is the investment cost and $\mathrm{R}$ is the expected IRR for investor. Noting that the value of Ic is changing with the change of the operation period, Fig (5). 
2- To calculate the lower limit of the concession period, an iterative process is used. The process starts by assuming the operation period (Y) equals the Payback period (determined before) Plus one year $(13+1=14)$.

3 - Enter the cost of the new operation activity.

4- Insert the $(\mathrm{Ic} * \mathrm{R})$ at the specified time $(\mathrm{Ic} * \mathrm{R}=$ $€ 522,116,000$ at $\mathrm{Y}=14)$. Noting that $\mathrm{R}=14 \%$, Ic= $€ 3,729,400,000$ where Ic is the construction cost + total trains cost +operation cost until 14 operation year.

5- Run Monte Carlo simulation to get the cumulative probability distribution of the NPV.

6- If the NPV $=0$, then the Lower limit of the concession period equals 19 years, otherwise increase the operation period by one year and acquire anew project schedule, then go to step 3 .

7-) Continuo increasing the operation period by one year until the NPV $=0$ to get the lower limit of the concession period.

8- In this case study, the NPV $=0$ will be found after 24 years' operation that mean the Lower limit of the concession period is 29 years.

\section{J. Upper Limit Concession Period}

1- After determining the lower limit of the concession period, define a start milestone activity (NAV), Fig (6). The cost assigned to that activity equals Net Asset Value (NAV). Note that the NAV = NAV for the line + NAV for the trains. The information needed for determining the NAV is gathered form the expert's opinion Table (7). Note that the trains renewals will be every 20 years and the cost of renewal is assumed as a percentage of the yearly operation and maintenance costs.

2- Enter the cost of construction activities, start milestone activity (Ic*R) and operation activities before the lower limit equal zero.

3- To calculate the upper limit of the concession period, an iterative process is used. The process starts by assuming the operation period (Y) equal the lower limit (determined before) Plus one year $(\mathrm{L}+1)=25$.

4- Enter positive and negative costs of all operation activities from $y$ to the end of line service life period.

5- Insert the NAV at the specified time, NAV = $€ 3,141,200,000$ at $\mathrm{Y}=25$.

6- Run Monte Carlo simulation to get the cumulative probability distribution of the NPV.

7- If the NPV $=0$ then the Upper limit of the concession period equal 30 years (25 years operation +5 years construction), otherwise increase the operation period by one year $(Y=26)$ and acquire new project schedule, then go to step 4.

8- Continue increasing the operation period by one year until the NPV $=0$ to get the upper limit concession period.

9- In this case study, the NPV $=0$ will be found after 38 years operation that mean the Upper limit of the concession period equals 43 years.

K. Analysis of results

Payback period $=18$ years

Lower limit of concession period equal $=29$ years
Upper limit of concession period $=43$ years

All of results including five years' construction Period.

The concession period lower and upper limits are greater than the payback period and lower than the project service life period (60 years after construction).

Figure 7 shows the cumulative probability distribution for NPV at the three cases (payback period, lower limit and upper limit). At payback period distribution the Probability of $\mathrm{NPV} \leq 0$ equal $83 \%$, at lower limit distribution the Probability of $\mathrm{NPV} \leq 0$ equal $50 \%$ and at upper limit distribution the Probability of NPV $\leq 0$ equal $28 \%$ and this logic because at payback period and lower limit the Probability of NPV $\leq 0$ should be high first and it decrease with every year increasing of them because making profit every year decrease the chance of $\mathrm{NPV} \leq 0$. For upper limit Probability of $\mathrm{NPV} \leq 0$ should be low first and increasing with every year increase of upper limit because increase of upper limit making less time for government to obtain profit from project which mean increasing probability of $\mathrm{NPV} \leq 0$.

Table (8) show results of other cases when changing in some project variables.

In Case (B) when decreasing toll rate to 10 euro the results will change as follow: Payback period equals 25 years, lower limit of concession period equals 37 years and upper limit of concession period equals 49 years and this logic because decreasing toll rate meaning that the private partner need more time than the first case to payback his investment and to make expected rate of return from the project and the upper limit will increase because the government will need more time to make NAV of Project at transfer time.

In Case (C) when increasing toll rate to 20 euro the results will change as follow: Payback period equals 13 years, lower limit of concession period equal 21 years and upper limit of concession period equal 36 years and this logic because increasing of toll rate meaning that private partner will take less time than the first case to payback his investment and make an expected rate of return but the upper limit will decrease because the government will need less time to make to make NAV of Project at transfer time.

In Case (D) when taking the effect of uncertainties only without the effect of risks noting that the uncertainty is a condition where there is no knowledge about the future events. the results will change as follow: Payback period equals 13 years, lower limit of concession period equals 23 years and upper limit of concession period equal 35 years and this logic because if is no risks in the project the private partner will take less time than the first case to payback his investment and make an expected rate of return but the upper limit will decrease because the government will need less time to make NAV of Project at transfer time.

In Case (E) when increasing the interest rate to $11 \%$ the results will change as follow: Payback period equals 22 years, lower limit of concession period equals 33 years and upper limit of concession period equals 46 years and this logic because increasing of interest rate that mean the private partner need more time than the first case to payback his investment and to make expected rate of return from the project and the upper limit will increase because the 
government will need more time to make NAV of Project at transfer time.

In Case $(\mathrm{F})$ when increase the number of passenger in each year by $10 \%$ the results will change as follow: Payback period equals 14 years, lower limit of concession period equals 24 years and upper limit of concession period equal 39 years and this logic because increasing number of passengers in each year means increasing of profit in each year then the private partner will take less time than the first case to payback his investment and make an expected rate of return but the upper limit will decrease because the government will need less time to make NAV of Project at transfer time.

Table (2)

CONSTRUCTION ACTIVITIES TIMING

\begin{tabular}{|c|c|c|c|}
\hline ID & Description & Duration & Start \\
\hline C10 & studies, acquisition, digs, right of way clearing and utility & 12 months & $1 / 1 / 2020$ \\
\hline C20 & infrastructure works (earthworks, viaducts, etc.). & 18 months & $31 / 12 / 2020$ \\
\hline C30 & Railway equipment's (track, signaling, electrification, etc.). & 24 months & $30 / 12 / 2020$ \\
\hline C40 & Tests and certification & 6 months & $1 / 7 / 2022$ \\
\hline
\end{tabular}

Table (3)

CONSTRUCTION ACTIVITIES COST

\begin{tabular}{|c|c|c|}
\hline ID & Description & Cost \\
\hline C10 & studies, acquisition, digs, right of way clearing and utility networks deviation. & $€ 264,000,000$ \\
\hline C20 & infrastructure works (earthworks, bridges, viaducts, tunnels, etc.). & $€ 2,079,000,000$ \\
\hline C30 & Railway equipment's (track, signaling, electrification, etc.). & $€ 627,000,000$ \\
\hline C40 & Tests and certification & $€ 330,000,000$ \\
\hline & $\sum$ & $€ 3,300,000,000$ \\
\hline
\end{tabular}

Table (4)

MAINTANANCE COST FOR PROJECT

\begin{tabular}{|c|c|c|}
\hline \multicolumn{3}{|c|}{ Maintenance cost for HSL } \\
\hline Number of kilos & Maintenance cost for one kilo & Total maintenance cost \\
\hline 220 & $€ 90000$ per year & Total Maintenance cost \\
\hline \multicolumn{3}{|c|}{ Maintenance of a high-speed train } \\
\hline Number of Trains & Maintenance of one train & $€ 4,000,000$ per year. \\
\hline 4 & $€ 1,000,000$ per year. &
\end{tabular}

Table (5)

THE YEARLY NUMBER OF PASSENGERS PREDICTED

\begin{tabular}{|c|c|c|c|}
\hline Year & Number of passengers & Year & Number of passengers \\
\hline 2025 & 26094995 & 2036 & 35184658 \\
\hline 2026 & 26921328 & 2037 & 36010991 \\
\hline 2027 & 27747661 & 2038 & 36837324 \\
\hline 2028 & 28573994 & 2039 & 37663657 \\
\hline 2029 & 29400327 & 2040 & 38489990 \\
\hline 2030 & 30226660 & 2041 & 39316323 \\
\hline 2031 & 31052993 & 2042 & 40142656 \\
\hline 2032 & 31879326 & 2043 & 40968989 \\
\hline 2033 & 32705659 & 2044 & 41795322 \\
\hline 2034 & 33531992 & 2045 & 42621655 \\
\hline 2035 & 34358325 & 2046 & \\
\hline
\end{tabular}

Table (6)

RISK REGISTER FOR CONSTRUCTION AND OBERATION RISKS

\begin{tabular}{|l|l|}
\hline \multicolumn{2}{|c|}{ Some of Construction Risks } \\
\hline Seasons Effect & \multicolumn{1}{c}{ Some of Operation Risks } \\
\hline Import / export restriction risks & Damage or failure risks \\
\hline Environmental risk & Accidents risks \\
\hline Restrictive site conditions & Lack of skilled maintenance crews \\
\hline Defective work & Damage/theft rail risks \\
\hline
\end{tabular}

Table (7)

INFORMATION NEEDED FOR NPV CALCULATION

\begin{tabular}{|c|c|c|}
\hline Information & Line & Train \\
\hline Service life period & 60 years & 20 year \\
\hline Residual value & $80 \%$ & $20 \%$ \\
\hline
\end{tabular}


Table (8)

SUMMRY OF RESULTS

\begin{tabular}{|c|c|c|c|c|}
\hline Case & Variables & $\begin{array}{c}\text { Payback } \\
\text { Period }\end{array}$ & Lower Limit & Upper Limit \\
\hline Case A & Standard data at section (5.7) & 18 years & 29 years & 43 years \\
\hline Case B & Take toll rate $=10$ Euro & 25 years & 37 years & 49 years \\
\hline Case C & Take toll rate $=20$ Euro & 13 years & 21 years & 36 years \\
\hline Case D & Take effect of uncertainties only & 13 years & 23 years & 35 years \\
\hline Case E & Take interest rate $=11 \%$ & 22 years & 33 years & 46 years \\
\hline Case F & Increase number of passenger in each year by $10 \%$ & 14 years & 24 years & 39 years \\
\hline
\end{tabular}

\begin{tabular}{l|l|l|l||l|l|}
2050 & Trains & 0 & $01 / 01 / 20$ \\
\hline C10 & Construction Activity 1 & 261 & $01 / 01 / 20$ \\
\hline C20 & Construction Activity 2 & 391 & $31 / 12 / 20$ \\
\hline C30 & Construction Activity 3 & 521 & $03 / 07 / 22$ \\
\hline C40 & Construcion Activity 4 & 132 & $01 / 07 / 24$ \\
\hline OP1 & operation year 1 & 261 & $01 / 01 / 25$ &
\end{tabular}

Figure 4. Beginning of operation period after construction period

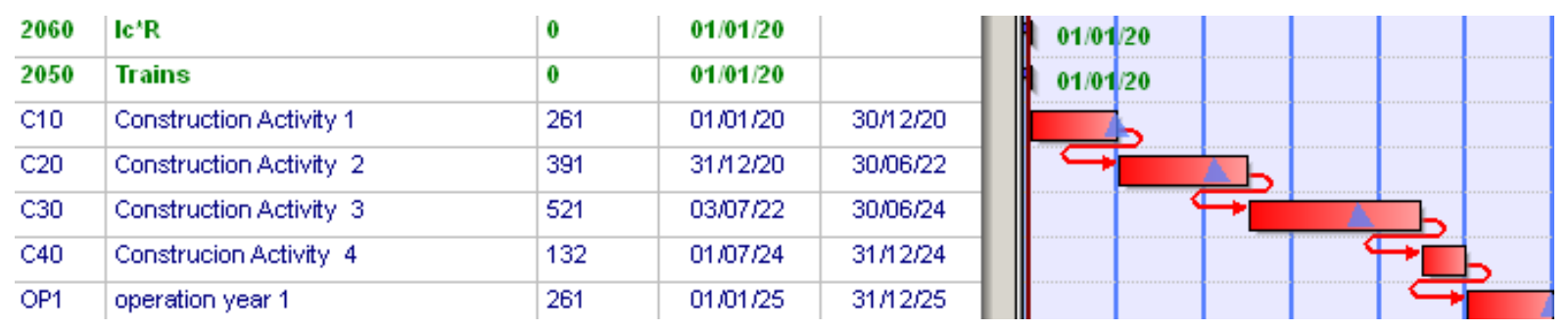

Figure 5. a start milestone activity at the beginning of the project called (I*R)

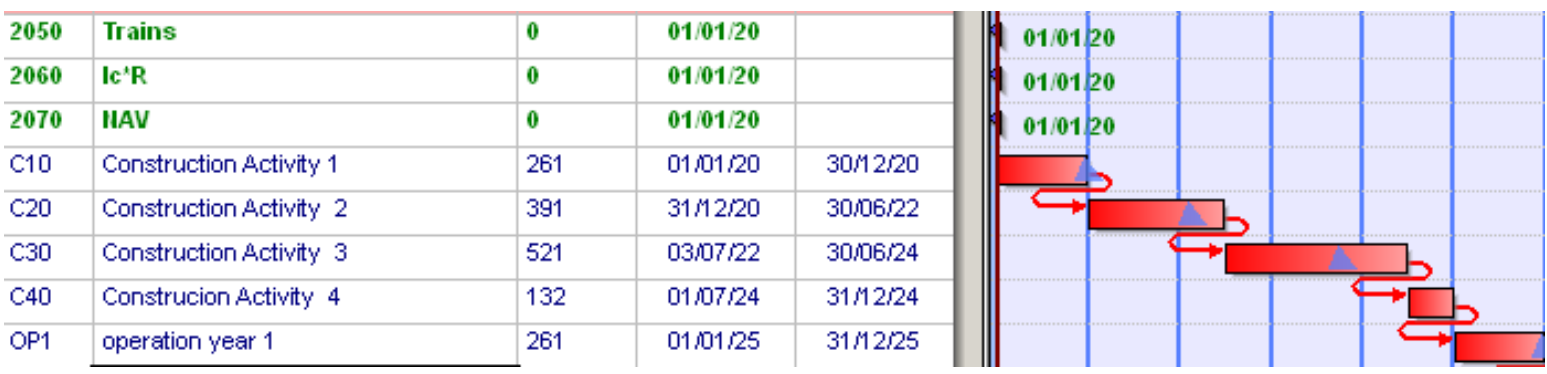

Figure 6. a start milestone activity at the beginning of the project called (NAV)



Figure 7. Cumulative probability distribution for NPV 


\section{CONCLUSION}

The determination of the concession period is a very important tool of the success of a BOT contract. Generally, a longer concession period is preferred by private investors but may bring loss to the government, however if the concession period is too short the private investment may reject the contract or have to increase the service fee so as to recoup the investment costs and make a profit which consequently transfers the risk burden to public users. This paper provides a methodology to determine the upper and lower limits of concession period of public private partnerships that would be useful both to the public and the private sector with the impact of risks and uncertainties taken into consideration. The paper developed a practical model for determination of the upper and lower limit of PPP projects. An accurate explanation of model inputs, outputs and methodology of work presented. the model is applied on a case of high-speed rail PPP project and accurate results were obtained. The model demonstrated its ability to determine the upper and lower limit of concession period with different values of interest rates and toll rates which are the most sensitive factor to results. The use of the model gives the users a clearly vision about the value of concession period that insure the private sector doesn't lose his investment and the government can benefit from the project before end of its service life.

\section{REFERENCES}

[1] Waziri, B. "Pareto Analysis of Critical Risk Factors of Build Operate and Transfer (BOT) Projects in Nigeria" Journal of Construction Business and Management. (2018), vol.2, No. 1.

[2] Xiong, W. and Zhang, X." Concession Renegotiation Models for Projects Developed through Public-Private Partnerships" J. Constr. Eng. Manage. (2014)

DOI:10.1061/(ASCE)CO.1943-7862.000843

[3] Thomas, S., JingzhuXie, N., Cheung Y. and Jefferies, M.” A simulation model for optimizing the concession period of publicprivate partnerships schemes" International Journal of Project Management. (2007), DOI: 10.1016/j.ijproman.2007.05.004.

[4] Hu, H. and Zhu, Y." Social Welfare-Based Concession Model for Build/Operate/Transfer Contracts" American Society of Civil Engineers. (2014) DOI: 10.1061/(ASCE)CO.1943-7862.0000920.

[5] JunnaLv, Gui Ye, Wei Liu, Liyin Shen, M. and Hongxia Wang "Alternative Model for Determining the Optimal Concession Period in Managing BOT Transportation Projects" American Society of Civil Engineers. (2014) DOI: 10.1061/(ASCE)ME.19435479.0000291.

[6] SHARMA, D. and CUI, O. "Design of Concession and Annual Payments for Availability Payment Public Private Partnership (PPP) Projects" American Society of Civil Engineers. (2012)

[7] Bagui, S. and Ghosh, A. "Design of Concession Period Considering Risk Management for a Road Project" Jordan Journal of Civil Engineering. (2013) Volume 7, No. 4.

[8] Nasirzadeh, F., Khanzadi, M. and Alipour, M. "Determination of Concession Period in Build-Operate Transfer Projects Using Fuzzy Logic" Iranian Journal of Management Studies. (July 2014). Vol. 7, No. 2.

[9] Zhang, X. and Abourizk, S. "Determining a reasonable concession period for private sector provision of public works and services" Canadian Journal of civil engineering. (2006), DOI:10.1139/L06010.

[10] Hanaoka, S. and Palapus, H. "Reasonable concession period for build-operate-transfer road projects in the Philippines" International Journal of Project Management. (2012), DOI: 10.1016/j.ijproman.2012.02.001
[11] Carbonara, N., Costantino, N. and Pellegrino, R. "Concession period for PPPs: A win-win model for a fair risk sharing" International Journal of Project Management. (2014), 0263-7863/\$36.00.

[12] Xueqing Zhang, M. "Win-Win Concession Period Determination Methodology" Journal of Construction Engineering and Management. (2009), DOI: 10.1061/_ASCE_CO.19437862.0000012 .

[13] Ke FENG, Shouqing WANG, Nan LI, Chunlin WU and Wei XIONG "Balancing Public and Private Interests Through Optimization of Concession Agreement Design for User-Pay PPP Projects" Journal of Civil Engineering and Management. (2018), vol 24 No 2.

[14] S. Thomas Ng, JingzhuXie, Martin Skitmore and Yau Kai Cheung "A Fuzzy Simulation Model for Evaluating the Concession Items of Public-Private Partnership Schemes" Automation in Construction. (2008).

[15] Mostafa, k., Farnad, N. and Majid, A. "Using Fuzzy-Delphi Technique to Determine the Concession Period in BOT Projects" Conference Paper. (October 2010), DOI: 10.1109/ICIFE.2010.5609396

[16] Zhang, X., Bao, H., Wang, H. and Martin Skitmore, M. "A model for determining the optimal project life span and concession period of BOT projects" International journal of Project Management. (2016), DOI: 10.1016/j.ijproman.2016.01.005

[17] International union of railways, Union International des Chemins de fer (UIC), Headquarters address:" UIC High Speed (2018)".

[18] Mahmoud Ahmed Mousa Ali "Opportunities for High-Speed Railways in Developing and Emerging Countries: A case study Egypt" Master thesis, Institute of Land and Sea Transport SystemsDepartment of Track and Railway Operations - TU Berlin- BerlinGermany (2009)

[19] Steve Guanwei Jang "A Concessionaire Selection Decision Model Development and Application for the PPP Project Procurement" $\mathrm{PhD}$ thesis, University of Southampton (2011).

[20] Li, B., Akintoye, A., Edwards, P. and Hardcastle, C." The Allocation of Risk in PPP/PFI Construction Projects in the UK" International Journal of Project Management. (2004), DOI: 10.1016/j.ijproman.2004.04.006

[21] Phang, S. " Urban rail transit PPPs: Survey and risk assessment of recent strategies" Research Collection School of Economics. (2007) Singapore Management University, DOI: https://doi.org/10.1016/j.tranpol.2007.02.001.

[22] Chan, A., Cheung, E., Ke, Y. and Wang, S." Understanding the risks in China's PPP projects: ranking of their probability and consequence" Engineering, Construction and Architectural Management. (2011), DOI 10.1108/09699981111165176

[23] AL-AZEMI, K., Bhamra, R. and Salman, A. "Risk Management Framework for Build, Operate and Transfer (BOT) Projects in Kuwait" Journal of Civil Engineering and Management. (2013), DOI: $10.3846 / 1392730.2013 .802706$.

[24] Gupta, A., Trivedi, M. and Kansal, R. "Risk Variation Assessment of Indian Road PPP Projects" International Journal of Science, Environment and Technology. (2013), Vol. 2, No 5.

[25] Sastoque, L., Arboleda, C. and Ponz, J."A Proposal for risk Allocation in social infrastructure projects applying PPP in Colombia" Procedia Engineering 145 (2016) 1354 - 1361.

[26] Elisabetta IOSSA and St'ephane SAUSSIER " public private partnerships in europe for building and managing public infrastructures: an economic perspective" Annals of Public and Cooperative Economics. (2018).

[27] Dalia Suliman Al Mohrez "Risk Management of Public Private Partnerships in Railway Projects in Egypt" Master Thesis, Faculty of Engineering, Cairo University. (2012). 